PAWEŁ TRIPPNER

\title{
Appraisal of Financial Situation of the Polish Banking Sector from 2008 to 2012
}

Paweł Trippner, Ph.D. University of Social Sciences in Łódź, Faculty of Management, Department of Finance

\section{Introduction}

The banking system is a key element of the financial system of a country. Banks, being institutions of public trust, play a vital role as financial intermediaries. They enable processes of converting savings into investments - both tangible and financial ones.

This study aims to characterize the functioning of banks as financial institutions, present their role in the economy, and describe methods of appraising the financial condition of those institutions according to various concepts offered by specialist literature.

In order to fulfil the above goal, the author puts forward a research hypothesis according to which the financial condition of the banking system deteriorated in recent years as a result of adverse economic phenomena, turbulence in financial markets, and problems experienced by banks in some EU countries.

2. Essence of Banks' Operations and Their Role in the Financial System of the Country

Pursuant to the Polish applicable law a bank is defined as ,.... legal person, established in 
accordance with provisions of applicable statutes, operating under authorization to perform banking transactions involving any risk for the funds entrusted to the bank and repayable in any way..."1.

The beginnings of the modern banking system can be traced to the 17thcentury Amsterdam where a financial information market evolved. The first central bank was set up in Sweden in 1668. A two-level banking system based on the superior role of a central bank as a bank of banks developed in 1913, shortly before the outbreak of World War I (Solarz J.K., 2001, pp. 67-68).

The most common type of banks are deposit-credit banks that obtain funds from their clients in the form of deposits. They are the sole institutions that may accept funds from their clients for a definite period of time and use them mainly to extend credit. They also operate in the financial market. For that purpose, they use part of funds collected in the form of deposits that have not been used in their lending activity. The funds are mainly invested in treasury debt securities characterized by low investment risk (Jaworski W., Zawadzka Z., 2008, p. 10).

A special role in the indirect transformation process is played by the financial market where supply of and demand for financial resources are matched. The supply side of the financial market is represented by entities having a financial surplus (savings): the financial market enables them to increase their financial resources. Those entities are referred to as suppliers of capital or investors (Wypych M., 2000, p. 114).

The demand side of the financial market is represented by entities seeking capital to meet their production or investment needs. Thus, they express their need for additional funds they want to use against payment for a precisely specified period of time. Those entities are referred to as recipients of capital or issuers and mainly include enterprises as well as local and central government units (Wypych M., 2000, p. 114).

According to specialist literature, financial intermediaries can be divided into two principal groups (Owsiak S., 2002, p. 224):

- institutions accepting deposits and creating money based on those deposits (including banks),

- institutions that create financial instruments not being money or act as nondeposit financial institutions.

The classification of financial intermediaries into the two groups is vitally

1 The Act of 29 August 1997 on Banking Law, Journal of Laws [Dz.U.] of 2011, No. 201, item 1181, as amended. 
important inasmuch as accepting deposits by banks is treated as money with the capability of using the money for extending credit. Monetary authorities take special care of the banking system since an increase in deposits results in a rise in money supply, which has specific consequences for the stability of prices. Thus, there are protective mechanisms working within contemporary banking systems that limit the risk of savings being lost (e.g. bank guarantee funds, duty to create obligatory reserves, advanced procedures of credit standing appraisal, legal security of credit). Also, the institution supervising the banking system, i.e. the Polish Financial Supervision Authority, has to give its consent to banks to pay dividends from earned net profits. Such a decision depends on the appraisal of a bank's stability by the PFSA².

When describing the role of banks as financial intermediaries, it can be indicated that, although the formal connection between suppliers of capital (saving entities) and recipients of capital (credit users) is severed, the economic connection is maintained (it is savings that are the source of capital and are used to finance investments).

Such a situation occurs when banks extend credit (which is mostly done by deposit-credit banks). The economic connection is broken when the bank uses deposited funds, for instance, to purchase securities or invest the funds in another manner (that mainly concerns investment banks) (Pietrzak B., Polański Z., (Eds.) 2006, p. 18).

\section{Methods of Appraising Banks' Financial Situation and Sources of Data for Analysis}

A reliable appraisal of the financial condition of every entity, banks included, requires using financial data that provide figures necessary to calculate financial ratios suggested by specialist literature.

The fundamental legal act that specifies principles of accountancy in Poland, inclusive of bank accounting, is the Accounting Act $^{3}$. The act lays down the principles of accountancy and the manner of the auditing of financial statements by auditors as well as rules for providing bookkeeping services. The provisions of the act are of a general nature; hence, they apply to all business entities keeping

2 The Act of 21 July 2006 on Financial Market Supervision, Journal of Laws [Dz.U.] of 2006, No. 157, item 1119.

3 The Accounting Act of 29 September 1994, Journal of Laws [Dz.U.] of 2002, No. 76, item 694. 
account books, while templates provided in attachments to the act differentiate between financial statements of banks and those of other entities.

In the Banking Law ${ }^{4}$, articles that regulate accountancy of banks are Article 111 Section 1 Point 5 specifying a duty to announce a balance sheet and an auditor's opinion for the last period subject to auditing as well as Articles 134 136 concerning auditing and audits of financial statements by auditors and their forwarding to the Polish Financial Supervision Authority.

Financial statements of a commercial bank consist of the following parts ${ }^{5}$ :

- profit and loss account,

- statement of total incomes,

- statement of financial situation (balance sheet),

- statement of cash flows,

- statement of changes in equity,

- explanatory notes.

In practice, the appraisal of a bank's financial situation uses two documents that provide necessary information, i.e. the profit and loss account and the balance sheet.

Specialist literature classifies methods of appraising banks' financial situation into two groups:

- classical methods based on financial ratios,

- non-classical methods based on the concept of economic income.

According to M. Capiga, the three crucial areas of banks' financial analysis include (Capiga M., 2010, p. 87):

- financial liquidity analysis,

- profitability evaluation,

- level of capital adequacy (solvency),

- appraisal of financing structure,

- level of management efficiency.

Other authors of specialist literature share the above-mentioned point of view. They include M. Marcinkowska who in her two books: Wartość banku and Ocena działalności instytucji finansowych introduces the above classification too. M. Iwanicz-Drozdowska in her book Zarzadzanie finansowe bankiem points to the need to analyse banks in the areas of financial liquidity, profitability, and solvency.

4 The Act of 29 August 1997 on Banking Law, Journal of Laws [Dz.U.] 2002, No. 72, item 665, Article 1.

5 The Accounting Act of 29 September 1994, Journal of Laws [Dz.U.] of 2002, No. 76, item 694. 
Analyses in this study apply ratios of the first two groups described by specialist literature.

Liquidity management consists in the constant forecasting of demand for funds on the part of the bank's clients (depositors and borrowers) as well as appraising sources of meeting that demand. The appraisal of financial liquidity employs the following measures.

Liquidity ratio (LR) that indicates the ability to cover liabilities repayable on demand by using the most liquid assets of the bank (Marcinkowska M., 2007, p. 343):

$$
\mathrm{LR}=\frac{\mathrm{LA}}{\mathrm{CL}}
$$

where:

LA - liquid assets; CL - current liabilities.

The higher the ratio, the higher the bank's safety level. Literature indicates that it should exceed 0.9 .

Liquidity ratio according to the IMF (IMFL) that juxtaposes relatively liquid financial resources of the bank with its total liabilities. The ratio defines the bank's financial capabilities in the event all deposits, independent of their contractual maturity dates, were suddenly withdrawn ${ }^{6}$.

$$
\mathrm{IMFL}=\frac{\mathrm{FR}+\mathrm{BD}}{\mathrm{TL}}
$$

where:

FR - financial resources; BD - amounts due from banks; TL - total liabilities.

Specialist literature considers the ratio above 0.1 to be satisfactory.

Liquid assets to total assets ratio (LATA) that indicates the liquidity level of the bank's assets (Marcinkowska M., 2007, p. 343).

$$
\text { LATA }=\frac{\text { LA }}{\text { TA }}
$$

where:

LA - liquid assets; TA - total assets.

6 Recommendation for the system of monitoring banks' financial liquidity. NBP. PFSA. GIBS. Warsaw 2002. 
The higher the ratio, the more stable the safety level of the bank.

Profitability ratios are a group of ratios defining efficiency of the bank's operations. The bank's profitability assesses the surplus of revenues from operations over costs, i.e. the bank's ability to generate profit. As a criterion for the bank's appraisal, profitability is a basic method to measure efficiency of the bank's operations.

Return on equity (ROE) - allows to determine the profitability of equity, i.e. the rate of return (Iwanicz-Drozdowska M., 2010, p. 72).

$$
\mathrm{ROE}=\frac{\mathrm{NP}}{\mathrm{E}}
$$

where:

NP - net profit; E - equity of the bank.

The higher the ratio, the greater the ability to pay dividends and increase the solvency ratio, and the better the chance of developing the bank's operations.

Return on assets (ROA) - The ratio indicates the rate of return on assets being the measure of operating efficiency that allows to assess the profit-earning capacity of assets held by the bank (Marcinkowska M., 2007, p. 323).

$$
\mathrm{ROA}=\frac{\mathrm{NP}}{\mathrm{TA}}
$$

where:

NP - net profit; TA - total assets of the bank.

Return on sales (ROS) - The ratio allows to determine what part of revenues remains in the bank in the form of net profit (Orechwa- Maliszewska E., Worobiej E., 2008, p. 85).

$$
\mathrm{ROS}=\frac{\mathrm{NP}}{\mathrm{R}}
$$

where:

$\mathrm{NP}$ - net profit; $\mathrm{R}$ - revenues of the bank.

Profit margin ratio (PM) - The structure of this ratio is very similar to ROS with the difference being that it applies operating income ${ }^{7}$. 


$$
\mathrm{PM}=\frac{\mathrm{NP}}{\mathrm{OI}}
$$

where:

$\mathrm{NP}$ - net profit; OI - operating income.

Specialist literature offers opinions critical of the ratio analysis as the most objective method of appraising the financial condition of enterprises (including banks).

The principal objection is that the analyses use the book profit, which impacts on the way in which obtained results are perceived. It is not an economic but only a bookkeeping point of view.

Numerous objections were made concerning the weakness of the book profit and its application in the ratio analysis of enterprises' financial position. According to A. Rappaport, the most important of those include (Rappaport A., 1998, p. 13):

- impact on the financial result of alternative accounting methods used,

- disregarding incurred risk,

- disregarding changes in the value of money over time, which prevents the comparison of obtained results in real terms,

- disregarding the dividend policy; hence the cost of equity in enterprises,

- disregarding investment outlays made.

Coinciding critical comments are also offered by other authors of specialist literature. A. Rappaport's views can be found in the books by T. Dudycz entitled Finansowe narzędzia zarzązania wartościa przedsiębiorstwa and by A. Ehrbar Strategia tworzenia wartości przedsiębiorstwa.

All the authors consider the method of appraising the financial situation of an enterprise based on the concept of economic income, which forms the basis for a measure called the Economic Value Added (EVA®), to be more objective.

The EVA ${ }^{\circledR}$ measure uses the Residual Income concept by Alfred Marshall. He was the first to draw attention to the defectiveness of bookkeeping measures that, when applied in determining the net profit, take only financial costs into account while completely disregarding equity costs borne by an enterprise. The Residual Income is defined as the sum of an enterprise's net profits reduced by shareholders' remuneration costs (cost of equity) (Dudycz T., 2002, p. 177).

The concept of the Economic Value Added was first presented by the Stern - Stewart \& Co consulting company at the end of 1980 based on the earlier presented Residual Income mechanism by Marshall (Helfert E.A. 1982, p. 505). 
The EVA is a measure that adjusts the earned book profit for incurred costs of equity, providing the actual value added for an enterprise.

When discussing the use of the EVA measure in the appraisal of banks' financial situation, M. Marcinkowska emphasizes the specificity of their operations consisting in a considerable share of external capital in their financing structure. The classical approach uses the measure of the average weighted cost of capital; however, due to the fact that banks, having a very high share of external capital, perform their tasks of a financial intermediary, it should be replaced with the cost of equity only (Marcinkowska M., 2003, p. 78).

Taking into account the above-mentioned assumptions, the formula of the Economic Value Added for a commercial bank would be as follows (Marcinkowska M., 2003, p. 100):

$$
\mathrm{EVA}=\operatorname{NOPAT}-(E * e)
$$

where:

EVA - Economic Value Added,

NOPAT - Net Operating Profit After Tax,

$\mathrm{E}$ - value of the bank's equity,

ec - cost of the bank's equity calculated as a price to book value ratio.

\section{Appraisal of Financial Situation of the Polish Banking Sector from 2008 to 2012}

The first area of the analysis is the appraisal of the banking sector's financial liquidity. It employs ratios presented in the preceding chapter. Results of the analysis are shown in the table and figure below.

Table 1. Liquidity ratios of the Polish banking sector from 2008 to 2012

\begin{tabular}{l|c|c|c|c|c}
\hline Ratio & $\mathbf{2 0 0 8}$ & $\mathbf{2 0 0 9}$ & $\mathbf{2 0 1 0}$ & $\mathbf{2 0 1 1}$ & $\mathbf{2 0 1 2}$ \\
\hline LR & 1.27 & 1.30 & 1.40 & 1.26 & 1.34 \\
\hline IMFL & 0.268 & 0.270 & 0.280 & 0.257 & 0.274 \\
\hline LATA & 0.221 & 0.226 & 0.229 & 0.219 & 0.235 \\
\hline
\end{tabular}

Source: own calculations based

on www.knf.gov.pl/opracowania/sektor bankowy/dane o rynku 


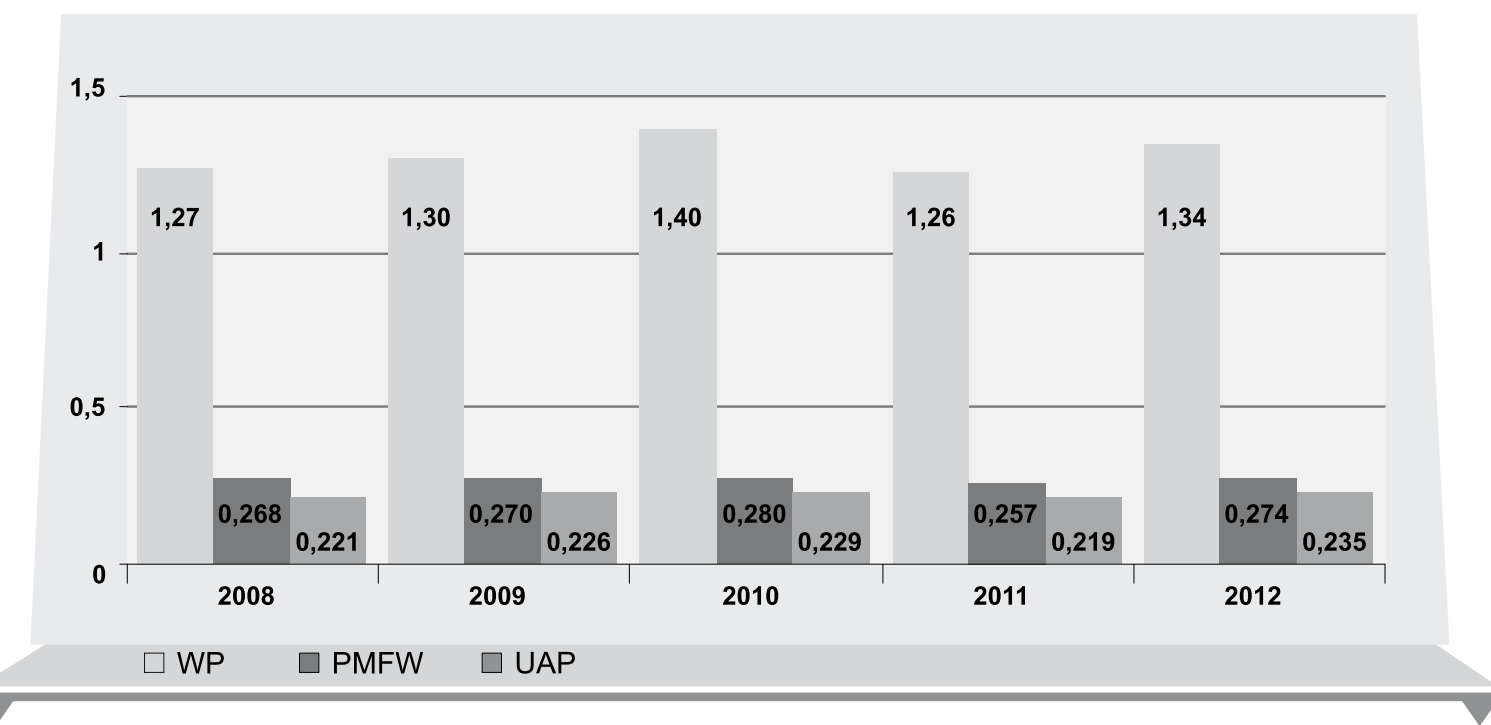

Figure 1. Graphic presentation of liquidity ratios of the Polish banking sector

Source: own work based on data in table 1

Based on the analysis of the above data, it should be stated that the liquidity of the banking sector remained at a good, satisfactory level in the past 5 years. Despite turbulence in financial markets of the European Union countries as well as of other parts of the world, the Polish banking sector proved resilient to adverse effects of those events. All of the analysed ratios indicated that the sector's liquidity declined in 2011 but then improved at the end of 2012, which is a positive phenomenon. It should be emphasized and appreciated that the Polish banking sector is characterized by high stability and safety levels in the period of deep trouble in other EU countries (e.g. Cyprus).

Another area of the analysis is the appraisal of profitability of the banking sector in Poland. Values of the ratios discussed in the methods part of this study are presented below.

Table 2. Profitability ratios of the Polish banking sector from 2008 to 2012

\begin{tabular}{l|c|c|c|c|c}
\hline Ratio & $\mathbf{2 0 0 8}$ & $\mathbf{2 0 0 9}$ & $\mathbf{2 0 1 0}$ & $\mathbf{2 0 1 1}$ & $\mathbf{2 0 1 2}$ \\
\hline ROS & $9.36 \%$ & $10.02 \%$ & $13.75 \%$ & $17.11 \%$ & $16.23 \%$ \\
\hline ROE & $7.42 \%$ & $7.98 \%$ & $9.85 \%$ & $12.06 \%$ & $10.89 \%$ \\
\hline ROA & $0.76 \%$ & $0.78 \%$ & $0.99 \%$ & $1.20 \%$ & $1.18 \%$ \\
\hline PM & $13.95 \%$ & $14.89 \%$ & $19.94 \%$ & $23.99 \%$ & $22.45 \%$ \\
\hline
\end{tabular}

Source: own calculations based

on www.knf.gov.pl/opracowania/sektor bankowy/dane o rynku 


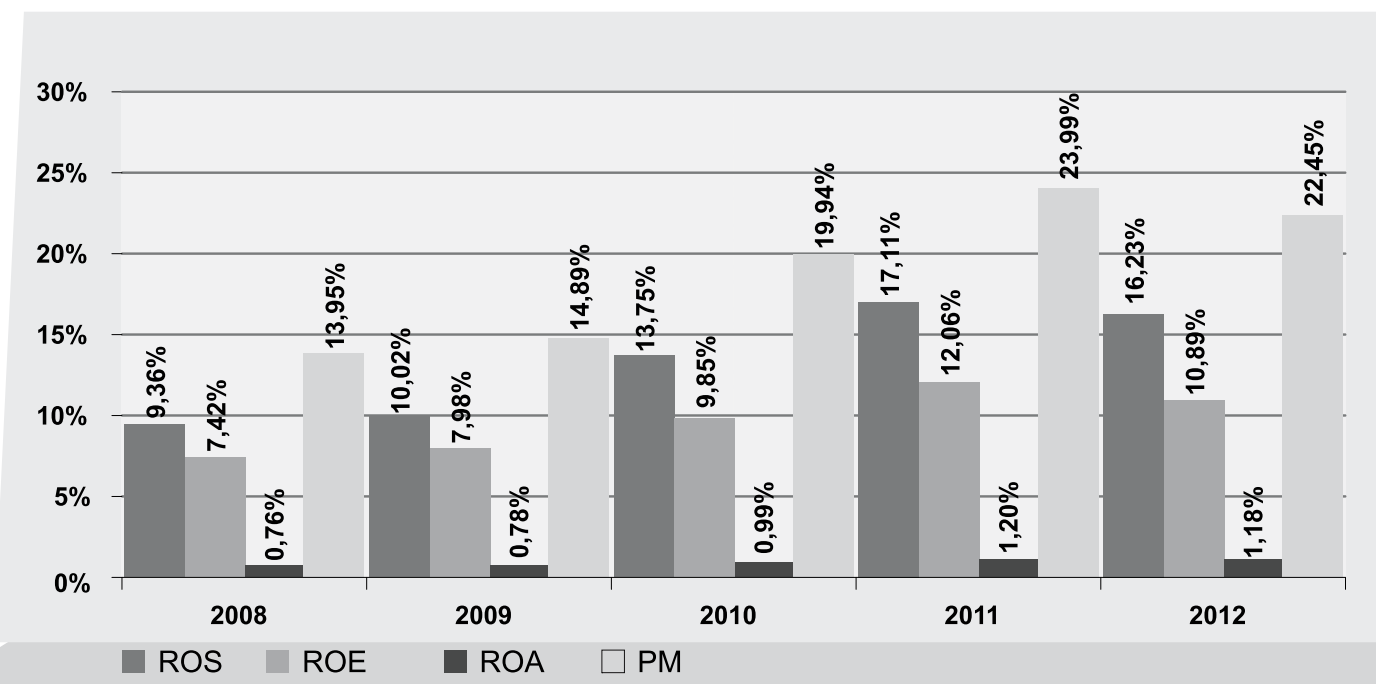

Figure 2. Graphic presentation of liquidity ratios of the Polish banking sector

Source: own work based on data in table 2

There was an upward trend observed in the profitability of the Polish banking sector in the first four analysed years. It was only 2012 that saw a fall in the sector's profitability, which was confirmed by all the applied ratios.

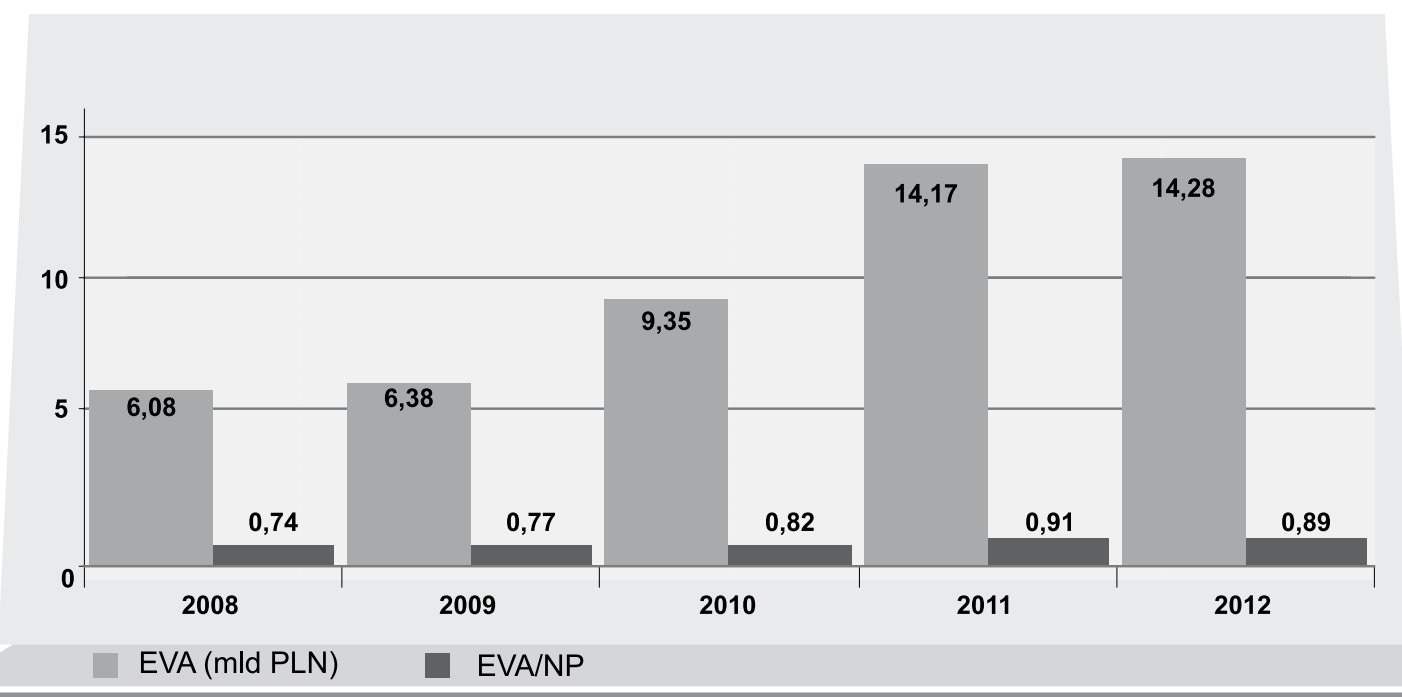

Figure 3. Economic Value Added for the Polish banking sector

Source: own calculations based on www.gpw.pl and www.knf.gov.pl 
It should be emphasized, however, that the profitability level of the sector can be regarded as moderate as the results received for the ratios are still lower than those recommended by specialist literature.

The last measure to be used to appraise the banking sector's condition is a measure alternative to financial ratios. The mechanism and essence of the Economic Value Added (EVA) were presented in the previous part of the study. Calculated results are shown in the figure below. Formula elements: EVA Economic Value Added, NP - Net Profit.

Data presented in the above figure indicate that the financial condition of the banking sector appraised by means of the EVA shows an upward trend. In the analysed period the Economic Value Added in the banking sector increased by over PLN 8 billion, which means a rise by over 130\%. The ratio of the EVA to the net profit of the sector should be regarded as good as it runs at the level of about $90 \%$ (the banks' cost of equity does not significantly affect their financial potential) despite its slight fall in the last of the analysed years.

\section{Concluding Remarks}

The banking sector is a key element of the financial system of every country. Banks are institutions of public trust and play a crucial role in the process of transforming savings into investments.

The aim of the study, set in the introduction, was fully met. The study presented the essence and role of banks in the financial system. It also discussed methods of appraising their financial condition as well as performed the analysis of situation in the banking sector from 2008 to 2012.

The research hypothesis put forward at the beginning of the study was not positively verified. Effects of the financial crisis, turbulence in financial markets, and problems experienced by banks in the European Union countries did not significantly influence the financial situation of the banking sector in Poland.

The level of financial liquidity should be considered good; profitability of the sector runs at a moderate but satisfactory level; while the appraisal of the financial condition employing the EVA measure enables to draw a conclusion that the financial potential of Polish banks increased significantly over the studied period.

An area for further research and analysis is the question of what instruments the banks were able to protect themselves from the negative effects of the financial crisis. Whether the reason should be searched for the active or passive side of banks' balance sheets? 


\section{Summary}

\section{Appraisal of Financial Situation of the Polish Banking Sector from 2008 to 2012}

The banking system is a very important element of the financial system of a country. As institutions of public trust, banks play a crucial role in the process of transforming savings into investments, which directly affects the country's economic development. Maintaining the banking sector in a good financial condition guarantees stability of the financial system and economic development of Poland.

The article aims to present the essence of operations of banks as financial institutions, present their role in the economy, and describe various methods of appraising their financial condition. In order to fulfil the above goals, a research hypothesis is put forward stating that the financial condition of the banking sector in Poland deteriorated in the analysed period as a result of an adverse impact of turbulence in financial markets and problems in banking sectors in the European Union countries.

Keywords: Banking system, Financial ratio, Financial condition analysis, Economic value added, Financial intermediary.

\section{Streszczenie}

Ocena sytuacji finansowej polskiego sektora bankowego w latach 2008 - 2012

System bankowy stanowi bardzo ważny element systemu finansowego państwa. Banki, jako instytucje zaufania publicznego odgrywają kluczową $\mathrm{w}$ procesie transformacji oszczędności w inwestycje, co bezpośrednio wpływa na rozwój gospodarczy kraju. Utrzymywanie się sektora bankowego w dobrej kondycji finansowej jest gwarancją stabilności systemu finansowego oraz rozwoju gospodarczego Polski.

Celem artykułu jest prezentacja istoty funkcjonowania banków, jako instytucji finansowych, zaprezentowanie ich znaczenia w gospodarce oraz charakterystyka różnych metod oceny ich kondycji finansowej.

Do realizacji powyższych celów sformułowana została hipoteza badawcza, według której, kondycja finansowa sektora bankowego 
w Polsce uległa pogorszeniu w analizowanym okresie, na skutek negatywnego oddziaływanie zawirowań na rynkach finansowych i problemów w sektorach bankowych w krajach Unii Europejskiej.

\section{Słowa}

kluczowe: System bankowy, Wskaźnik finansowy, Analiza kondycji finansowej, Ekonomiczna wartość dodana, Pośrednik finansowy.

\section{References}

1. Capiga M. (2010), Zarządzanie bankiem [Bank management], Wydawnictwo Naukowe PWN, Warsaw.

2. Dudycz T. (2002), Finansowe narzędzia zarządzania wartością przedsiębiorstwa [Financial instruments of enterprise value management], Wydawnictwo AE we Wrocławiu, Wrocław.

3. Iwanicz-Drozdowska M. (2010), Zarzadzanie finansowe bankiem [Bank financial management], PWE, Warsaw.

4. Jaworski W., Zawadzka Z. (2008), Bankowość [Banking], Poltext, Warsaw.

5. Helfert E.A. (1982), Techniques of financial analysis, R.D. Irwin, Homewood, IL.

6. Marcinkowska M. (2007), Ocena działalności instytucji finansowych [Appraisal of operations of financial institutions], Difin, Warsaw.

7. Marcinkowska M. (2003), Wartość banku [Bank value], UŁ, Łódź.

8. Orechwa-Maliszewska E., Worobiej E. (2008), Sprawozdawczość i analiza finansowa banku [Reporting and financial analysis of the bank], Wyższa Szkoła Finansów i Zarządzania w Białymstoku, Białystok.

9. Owsiak S. (2002), Podstawy nauki finansów [Fundamentals of finance learning], PWE, Warsaw.

10. Pietrzak B., Polański Z., (Eds.) (2006), System finansowy w Polsce [Financial system in Poland], PWN, Warsaw.

11. Rappaport A. (1998), Creating shareholder value, The Free Press, New York.

12. Solarz J.K. (2001), Międzynarodowy system finansowy [International financial system], Biblioteka Managera i Bankowca, Warsaw.

13. Wypych M. (2000), Finanse $i$ instrumenty finansowe [Finance and financial instruments], Absolwent, Łódź.

14. The Act of 29 August 1997 on Banking Law, Journal of Laws [Dz.U.] of 2011, No. 201, item 1181, as amended.

15. The Act of 21 July 2006 on Financial Market Supervision, Journal of Laws [Dz.U.] of 2006, No. 157, item 1119.

16. Recommendation for the system of monitoring banks' financial liquidity (2002). NBP. PFSA. GIBS. Warsaw. 